\title{
BEYOND RATIONALITY? JUDICIAL REVIEW AND PUBLIC CONCERN IN THE EU AND THE WTO
}

\author{
Chris Hilson, Professor of Law, The University of Reading" \\ Introduction
}

Within the literature on risk regulation, there are, broadly speaking, two camps. On the one hand, there are the "rationalists", who place considerable emphasis on apparently objective methods such as scientific risk assessment and cost-benefit analysis. ${ }^{1}$ Rationalists regard public perceptions of risk as "irrational" and decry the perverse effects that these can have on regulatory priorities. In their view, society allocates too many of its resources to regulating risks which the public perceives as significant but which science suggests are relatively minor; and not enough to risks which are proven killers but which the public perceives as much less significant. On the other hand, there are the populists, ${ }^{2}$ who question the rationalist assumption that scientific risk assessment is wholly objective, and who argue that public perceptions - far from being irrational - are simply exhibiting an alternative rationality. From the populist perspective, public perceptions of risk are democratically important and should be factored into the regulatory decisionmaking process from the outset.

This article is not just about the public perception of risk however. It is about public concern more generally. With many risk activities, the public may well be concerned because they perceive a risk to their own health or to the environment despite the science suggesting that there is no risk. Nevertheless, they may also have concerns about the activity on broader ethical, religious or political grounds. With genetically modified organisms (GMOs), for example, the public may - despite the lack of clear scientific evidence of a risk - perceive GMOs as a health risk. However, they may also have religious concerns about humans "playing God" with nature, or political concerns about multinational biotech companies monopolising the food sector.

* I am grateful to Veerle Heyvaert, Maria Lee and an anonymous referee for their comments. All errors remain my own.

1 The leading exemplar being Sunstein, Risk and Reason: Safety, Law, and the Environment (Cambridge University Press, 2002). See also Breyer, Breaking the Vicious Circle: Toward Effective Risk Regulation (Harvard University Press, 1993).

2 See e.g. Winickoff, Jasanoff, Busch, Grove-White and Wynne, "Adjudicating the GM Food Wars: Science, Risk, and Democracy in World Trade Law" (2005) 30 Yale J. Int'1 L. 81; ESRC Global Environmental Change Programme, The Politics of GM Food: Risk, Science and Public Trust, Special Briefing No. 5 (University of Sussex, 1999); Marris, Wynne, Simmons \& Weldon, Public Attitudes to Agricultural Biotechnologies in Europe (2001), available at http://www.lancs.ac.uk/depts/ieppp/pabe/; Gillette and Krier, "Risk, Courts, and Agencies" (1990) 138 U. Pa. L. Rev. 1027. 
The aim of this article is to examine the extent to which, under EU and WTO law, decision-makers are legally entitled to take public concern into account An answer to this question will necessarily involve an examination of how the issue of public concern has been dealt with by the European Court of Justice and the dispute resolution bodies of the WTO, in reviewing the decisions or actions of states or supranational authorities. ${ }^{3}$ From an analysis of these issues, we should be able to consider the extent to which these judicial bodies have been willing or able to move beyond the apparent rationality of science to take public concern into account. ${ }^{4}$

\section{EU Case Law on Public Concern}

Before examining the cases themselves, it is worth noting that, in a number of them, public perception of risk or broader public concern is raised indirectly via the notion of consumer confidence. In essence, while science may have revealed no evidence of risk associated with a particular product, the public may nevertheless perceive there to be a risk or object to it on broader grounds and thus reject the product. From the point of view of public decision-makers wanting to support producers, it becomes a matter of attempting to restore consumer confidence in the relevant product confidence or trust that has been dented by a perception of risk (albeit one that may not be objectively justified by way of scientific evidence) or conflict with wider values. Consumer confidence in these cases therefore acts as a proxy for public concern. ${ }^{5}$

Turning now to the cases, the issue of public concern was first raised in two key cases involving the well-known "Beef Hormones" controversy. ${ }^{6}$ In $U K \mathrm{v}$

3 Although the respective cases are not precisely on all fours (in that, as we shall see, the WTO ones concern free movement of goods and the EU ones concern review of Community legislative action rather than Member State regulations impeding free movement), they both involve "judicial review" of political action. On the WTO from a judicial review perspective, see Scott, "European Regulation of GMOs: Thinking About 'Judicial Review' in the WTO”, Jean Monnet Working Paper No. 04/04, available at http://www.jeanmonnetprogram.org/papers/04/ 040401.html

4 The assumption made in the article is thus that science and public concern are separate, with the latter typically being used to refer to scientifically unjustified risk perceptions (on the basis that there is no evidence of risk) and/or other, e.g. political/ethical-type concerns. However, N.B. that public concerns can of course be scientifically justified and may be incorporated within scientific assessment (e.g. public framing of the risk or identification of risk pathways may be more extensive than those initially adopted by scientific experts). N.B. also that some in the populist camp claim that even less evidentially specific, more speculative public anxieties about remaining uncertainties are still, in a sense, scientific.

5 Of course consumer confidence cannot always act as a proxy for public concern, as the public may also be concerned about risks that are not closely related to a consumable product.

6 Which will be returned to below in the section on the WTO. Both the EC and WTO aspects of the saga are discussed in: Scott, "On Kith and Kine: Trade and Environment in the EU and WTO" in Weiler (ed.), The EU,WTO and NAFTA: Towards a Common Law of International Trade (OUP, 2000), p.125; Joerges, "Law, Science and the Management of Risks to Health at the National, European and International Level - Stories on Baby Dummies, Mad Cows and Hormones in 
Council, ${ }^{7}$ the applicant claimed, first, that Council Directive 85/649 - which banned the use of certain growth-promoting hormones in livestock farming was adopted using the wrong legal base. The UK claimed that the Directive - which was adopted solely on the basis of Article 43 (now 37) of the Treaty, requiring only qualified majority voting - should have been based on Article 100 (now 94), which required unanimity and which would therefore have enabled the UK to reject the measure. The aim of the Directive, according to the recitals in its preamble, was to protect human health and consumer interests with a view to eliminating distortions of competition and bringing about an increase in consumption of the product in question. ${ }^{8}$ While the UK effectively conceded that the Directive had a legitimate agricultural policy aim, it claimed that the protection of public health was the predominant aim and that this required recourse to Article 100. ${ }^{9}$ However, the Court rejected this argument, stating that the agriculture Article 43 legitimately included health objectives..$^{10}$ In relation to this first argument, the case is of little direct interest from the point of view of public concern - other than as a counterexample to most of the cases considered below, where applicants have tended to argue not that the relevant measure was aimed at public health but rather that it was not. In this respect, the UK's first argument also sits rather uneasily with its second claim considered below which, as we shall see, suggests that public health was not really the main objective.

The UK's second claim was more directly linked to the issue of public concern - at least in the Advocate General's Opinion, if not it the ruling of the Court itself. The UK claimed that the reasons for Directive 85/649 were insufficiently stated. According to the UK, a scientific report, drawn up as a result of a duty in an earlier Directive,${ }^{11}$ pointed against the need for a ban on scientific, health grounds. In its statement of reasons, Directive 85/649 had failed to advance any reasons for not taking the findings of that report into account. On this point, Advocate General Lenz began by observing that, while the Commission had to take the report into account in drafting its proposal for a directive, the Council was under no duty to do so. ${ }^{12}$ In a passage that is worth quoting at length, he then went on to state that:

"Moreover, it is clear from the arguments put forward in the proceedings that, in view of the reaction of the Economic and Social Committee and of the Parliament to the first Commission proposal of June 1984, the predominant concern of the Commission, and thereafter of the Council as well, was

Beef" (2001) 7 Col. J. of Eur. L. 1; and Majone, "What Price Safety? The Precautionary Principle and its Policy Implications" (2002) 40 J.C.M.S. 89.

7 Case 68/86 UK v Council [1988] E.C.R. 855. For comment on this case, raising a number of the issues discussed here, see Joerges (n.6 above) pp.9-10; and Majone (n.6 above) pp.96-97

8 Judgment, para. 20.

9 See para.16 of the A.G.'s Opinion.

10 Para.12.

11 Art.8 of Dir. 81/602, which stated that "the Commission shall submit to the Council a report on the experience acquired and scientific developments, accompanied, if necessary, by proposals which take these developments into account."

12 Para.38. 
not so much the safeguarding of the health of consumers (a problem which the scientific group considered above all) but to take into account the interests of consumers in general (since it could be seen that meat from animals treated with hormones is widely rejected). That attitude is without question one of the matters falling under "experiences acquired" referred to in Article 8 of Directive $81 / 602$. Once the emphasis of the intended measure centred on that aspect, however, there was really no reason to examine the health problem in particular, which had evidently been the main focus of interest in the past, and so the fact that in the preamble to the contested directive the Council did not go into the partial findings of the scientific group, which the Commission did make available to the Council, certainly cannot be regarded as a failure to state reasons." 13

Here he is stating, in effect, that because the measure was mainly driven by consumer concern, it did not matter that the Council failed to refer to a scientific report stating that there was no risk to health. The suggestion is that, whatever scientists said as to the safety of hormones in meat in such a report, consumers would continue to perceive a health risk, or object to it on broader grounds, ${ }^{14}$ and thus reject such meat. Nevertheless, while the Advocate General's Opinion squarely addressed public concern in this way, the Court itself chose to base the relevant part of its ruling solely on the narrow, initial point about the lack of a legal duty on the part of the Council to take the report into account. ${ }^{15}$

Fedesa ${ }^{16}$ concerned a challenge to the validity of the successor ${ }^{17}$ hormones Directive 88/146, which similarly prohibited the use of certain hormones in livestock farming. As the Court pointed out, ${ }^{18}$ the first recital in the preamble to the Directive stated that assessments of the effect on human health of those substances varied in the different national regulations. The second recital stated that the Council therefore considered it necessary to lay down rules ensuring that "all consumers are able to buy the products in question under largely identical conditions of supply and that these products correspond to their anxieties and expectations in the best possible manner". The recital went on to state that the Council considered that such a course of action was bound to bring about an increase in consumption of the product in question. In essence, the case was centred around these first two recitals.

13 ibid., emphasis added.

14 See A.G. Mischo in C-331/88 $R$ v MAFF, ex parte Fedesa [1990] E.C.R. I-4023, where he observes that public campaigns against the use of hormones in agriculture were not "solely based on fears as to the harmful nature of hormones, but were also the manifestation of a more general trend in public opinion, namely a growing aversion on the part of the public to the use of chemical products in agriculture" (para.16).

15 Paras.35-36 of the Judgment.

16 n.14 above.

17 The earlier Dir. 85/649 having been annulled in $U K \mathrm{v}$ Council, n.7 above (not, as we have seen, for having the wrong legal base or for insufficiency of reasons, but on another, more technical procedural ground).

18 Para.6. 
The applicants challenged the Directive on a number of grounds, but only those of legal certainty, legitimate expectations and proportionality involved the issue of public concern. In relation to the former two, it was argued during the proceedings "that the directive lacked any scientific basis justifying the public-health considerations and consumer anxieties which underlay its adoption and that it frustrated the legitimate expectations of traders, who were entitled to expect that the substances in question would not be prohibited in the absence of any objectively based doubt as to their safety, efficacy and quality." 19 On the initial issue of legal certainty stricto sensu, the Court was prepared to assume that the principle requires any measure adopted by the Community institutions to be founded on a rational and objective basis. It is, of course, science which tends to be regarded as rational and objective, and the Commission's scientific evidence had been that the relevant hormones posed no health risk to consumers. ${ }^{20}$ In these circumstances, one might think that the ban was not founded on a rational and objective basis, because science did not support it. Nevertheless, according to the Court, this was a highly discretionary policy area where the Court would only intervene if the Council had manifestly exceeded the limits of its discretion. In the Court's view, it was not therefore necessary for the Council to prove that the Commission's evidence as to the safety of the relevant hormones was unsound. Faced "with the divergent appraisals by the national authorities of the Member States . . the Council remained within the limits of its discretionary power in deciding to adopt the solution of prohibiting the hormones in question, and respond in that way to the concerns expressed by the European Parliament, the Economic and Social Committee and by several consumer organizations." ${ }^{21}$

At first sight, one might think that use of the rather technical word "appraisal" 22 implies that the divergent Member State appraisals were scientifically based. On this view, the Court was stating that the Council had not committed a manifest error in not following the Community's rational and objective science because its action was supported by the also rational and objective scientific appraisals of a number of Member State authorities. ${ }^{23}$ However, if one looks at the UK's submissions in the case, it becomes clear that no scientific evidence had been adduced in support of those Member

19 Para.7.

20 See A.G. Mischo's Opinion, para.15.

21 Para.9. On these appraisals and concerns, see further A.G. Mischo's Opinion, para.16. Scott and Vos have drawn attention to the fact that the concerns taken into account go beyond those held by the directly elected European Parliament (EP), thus suggesting that the democratisation of risk goes beyond the confines of representative democracy alone ("The Juridification of Uncertainty: Observations on the Ambivalence of the Precautionary Principle within the EU and the WTO" in Joerges and Dehousse (eds.), Good Governance in Europe's Integrated Market (OUP, 2002), p.253 at p.284).

22 Or indeed the word "assessment" used in the first recital of the preamble to the Dir., which perhaps suggests a scientific risk assessment.

23 On this reading: the fact that the ban also reflected wider public concerns (as expressed by the EP, the ESC and consumer organisations) is presented as a secondary, supporting factor; and, unusually, public concerns here were backed up by Member State scientific support. 
State appraisals or assessments. ${ }^{24}$ In other words, it is more likely that the "divergent appraisals" were non-scientific and based on national public concern. Seen from this stance, the ruling can be seen as offering explicit support for the consideration of public concern over science. ${ }^{25}$

Neither, according to the Court, did the Directive frustrate the legitimate expectations of traders. First, traders should not have assumed that the Community scientific advice would be followed since, under the terms of the relevant Directive, only the Commission and not the Council were legally obliged to take this advice into account. ${ }^{26}$ And secondly, "in view of the divergent appraisals which had been made, traders were not entitled to expect that a prohibition on administering the substances in question to animals could be based on scientific data alone." 27 Again, there are two possible interpretations of this latter statement. On the one hand, it could be interpreted to mean that, given that there were competing scientific views at play (national authorities versus Community), it was impossible for traders to expect the prohibition to be founded on just science and that public concern was thus bound to play a deciding role. On the other hand - and more plausibly given the UK's submissions mentioned above - it could be seen as lending support to a reliance on broad EU public opinion in place of science.

As for proportionality, the applicants had argued that the Directive infringed the principle, inter alia, because an outright ban was not necessary: consumer anxieties could have been allayed using straightforward information and advice. ${ }^{28}$ In a somewhat cryptic passage, the Court replied to this as follows:

"As regards the arguments which have been advanced in support of the claim that the prohibition in question is not necessary, those arguments are in fact based on the premise that the contested measure is inappropriate for attaining objectives other than that of allaying consumer anxieties which are said to be unfounded. Since the Council committed no manifest error in that respect, it was also entitled to take the view that, regard being had to the requirements of health protection, the removal of barriers to trade and distortions of competition could not be achieved by means of less onerous measures such as the dissemination of information to consumers and the labelling of meat." 29

What the Court appears to be saying here is that the measure was potentially appropriate for securing a number of objectives. One of these objectives was

${ }^{24}$ See A.G. Mischo's Opinion, para.10.

25 Scott and Vos' brief discussion of the case is along these lines. They are critical of the Court for taking into account broad public concern without fully examining the status of these concerns or questioning their legitimacy (n.21 above, pp.284285).

26 Para.10. Cf. UK v Council (n.7 above), where a similar point was made in relation to a claim about insufficiency of reasons (as opposed to legitimate expectations here).

27 Para.10.

28 Para.12.

29 Para.16. 
allaying (allegedly unfounded) consumer anxieties and the Council had committed no manifest error in concluding that a ban was necessary to achieve this objective. However, that was by no means the only one. Others included health protection and the removal of barriers to trade and distortions of competition and, according to the Court, the Council was again entitled to conclude that a ban was necessary to achieve these objectives and that lesser, informational measures would not be sufficient. ${ }^{30}$

Having tackled hormones, the Community set its sights next on the use of antibiotics in agriculture. Again, its controls in this area gave rise to a number of challenges by disgruntled producers. Boehringer ${ }^{31}$ involved annulment proceedings brought against a Community ban on the marketing of beta-agonists for use in livestock production. As the Court of First Instance (CFI) noted, these antibiotics had two uses: one, in low doses, as a veterinary medicinal product which did not threaten public health; and the other, in extremely high doses, for the purpose of fattening cattle, which was potentially harmful to humans (producing sickness on eating the relevant meat). ${ }^{32}$ The ban covered both of these uses. Boehringer claimed that this general ban was disproportionate and that specific use for therapeutic purposes should have been allowed to continue, with appropriate control measures in place to prevent unscrupulous farmers from abusing the therapeutic option. The CFI disagreed. It noted first that proportionality involves considering, inter alia, whether the measures in dispute are necessary for achieving their aim. ${ }^{33}$ The aim or objective of the relevant Directive $^{34}$ was said to be twofold: to protect public health and to meet consumer concerns as required by the common agricultural policy. ${ }^{35}$ In relation to the public health aim, the Court stated that it could not be demonstrated that the Council had made a manifest error of assessment in holding that the general ban was preferable from the point of view of protecting public health, particularly given the uncertainties surrounding the effectiveness of control measures on therapeutic uses and their high cost to the public purse. ${ }^{36}$ In relation to the common agricultural policy aim, the CFI ruled that:

"Furthermore, even if protection of public health takes priority over all other considerations, the protection of consumer confidence is equally important. It is undisputed that at least a section of the public and the professions involved together with many Members of the European Parliament were in favour of an outright ban on beta-agonists, and that their anxieties would not have been allayed by the establishment of

30 In this respect, the Court's judgment appears to mirror the A.G.'s Opinion (see paras.17, 29, 33, and 39-42 of his Opinion). In reality of course, these "alternative" objectives are also potentially associated with public concern - a point that will be returned to towards the end of this section.

31 Cases T-125/96 and T-152/96 [1999] E.C.R. II-3427.

32 i.e., with this latter use, it is antibiotics rather than hormones being used as growth-promoters.

33 Para.76.

$3496 / 22$

35 Para.77.

36 Paras.90-97. 
control mechanisms, however effective they might have been in purely operational terms. It is also undisputed that, in many Community countries, information campaigns going so far as to issue calls for the boycott of meats containing hormones were launched by consumer associations in the past. In those circumstances, and taking into account the growing use of beta-agonists for the purpose of fattening cattle artificially, the Council cannot be regarded as having committed a manifest error of assessment in holding that only a general prohibition was capable of restoring consumer confidence." 37

Perhaps not surprisingly given the dual objective of the Directive, the CFI here is unequivocal in attaching equal importance to consumer perceptions of risk. Even if specific control mechanisms were completely effective in tackling the risk to public health from potential abuse of the therapeutic availability of beta-agonists, public anxiety or fear, albeit scientifically unjustified, would still it seems have supported a general ban of both growth promoting and therapeutic uses.

The more recent Pfizer $^{38}$ case involved a challenge on the grounds of, inter alia, misuse of powers. At the heart of the case was an antibiotic called virginiamycin, which was added to animal feedingstuffs in low doses to act as a growth promoter. Although scientifically unproven, the risk was that the antibiotic resistance developed in animals to this drug would be transferred to humans. ${ }^{39}$ This risk led certain Member States and eventually the Community itself to ban its use as a feed additive. The ban was implemented by way of a Regulation, ${ }^{40}$ based on powers in the relevant Directive, ${ }^{41}$ which only provided for action to be taken on human or animal health, or environmental grounds. Pfizer alleged that the Community ban was actually driven by the sole aim of "creating a favourable political impression in the eyes of the press and public opinion, which is tantamount to a misuse of powers." 42 In response, the CFI ruled that this was not borne out by the documentary evidence, which revealed that the contested regulation pursued, above all else, public health objectives. ${ }^{43}$ It then added that:

In any event, the restoration of consumer confidence can in such circumstances also be an important objective which may justify even substantial economic consequences for certain traders. ${ }^{44}$

The case thus appears to suggest that the restoration of consumer confidence can be a legitimate secondary objective alongside the protection of public health even when - as in this case - the relevant legal base for the measure does not provide for any action on that basis and where the restoration of

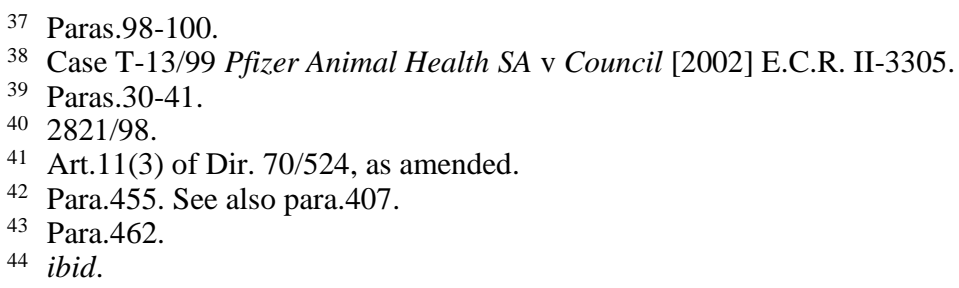


consumer confidence is not explicitly mentioned as an objective in the measure itself.

Just as the Pfizer, antibiotics case involved a misuse of powers challenge, so in the principal UK BSE ${ }^{45}$ case ${ }^{46}$ the UK similarly claimed, inter alia, that the Commission's Decision 96/239 - which had imposed a ban on exports of live cattle and beef products from the UK - was unlawful on this ground. The UK maintained that the relevant Directives ${ }^{47}$ on which the Commission's Decision was based provided only for measures to be taken on health grounds and that the Commission had in fact acted for economic reasons to reassure consumers, to stabilise the relevant markets and to safeguard the beef industry. ${ }^{48}$ The relevant recitals of the preamble to the Decision were as follows:

"Whereas, under current circumstances, a definitive stance on the transmissibility of BSE to humans is not possible; whereas a risk of transmission cannot be excluded; whereas the resulting uncertainty has created serious concern among consumers. ${ }^{49}$

The export ban Decision was prompted by the statement of the UK Spongiform Encephalopathy Advisory Committee (SEAC), to the effect that exposure to BSE was the most likely explanation of the recent cases of variant Creutzfeldt-Jakob Disease (vCJD) in humans. Nevertheless, SEAC was also careful to point out that there was no direct evidence of a link, and the EU Scientific Veterinary Committee (SVC) endorsed this. ${ }^{50}$ It was, in other words, still a matter of scientific uncertainty: scientists were not claiming to be certain of a link. Furthermore, neither SEAC, nor, initially, the SVC, had recommended going much beyond the existing controls ${ }^{51}$ on BSE, which had been in place for some time. ${ }^{52}$ While the UK Government initially followed these recommendations, it very quickly decided to go beyond the scientific advice it had been given to introduce the Over Thirty Months Scheme (OTMS), under which all of the highest-risk, older cattle would be kept out of the food chain. ${ }^{53}$ The reasons for this were partly

45 Bovine Spongiform Encephalopathy or "mad cow disease". For a wide-ranging analysis of a number of the risk regulatory issues associated with the BSE crisis, see further Little, "BSE and the Regulation of Risk" (2001) 64 M.L.R. 730. For discussion of the EU aspects, see Neyer, "The Regulation of Risks and the Power of the People: Lessons from the BSE Crisis" (2000) 4(6) European Integration Online Papers; and Joerges (n.6 above). On comitology aspects, see Krapohl, "Risk Regulation in the EU Between Interests and Expertise: The Case of BSE" (2003) 10 J.E.P.P. 189.

46 Case C-180/96 UK v Commission [1998] E.C.R. I-2265.

47 Art.9 of Dir. 89/662, as amended; and Art.10(4) of Dir. 90/425, as amended.

48 Para.35.

49 Emphasis added.

50 Case C-180/96 (n.46 above), paras.9 and 13.

51 Such as removing high-risk "Specified Bovine Offal" ( $\mathrm{SBO}-$ e.g. head and spinal cord) from the food chain.

52 SEAC's principal recommendation was that cattle over 30 months be deboned in licensed plants, with the nervous and lymphatic tissue trimmings designated as SBO and thus kept out of the food chains.

53 i.e. the whole carcass and not just SBO material. 
practical, ${ }^{54}$ but were partly also a matter of accepting the need to go beyond the science in order to reassure the public and maintain public confidence in British beef. ${ }^{55}$ The major supermarkets had made it clear that they would not sell any meat from cattle aged over 30 months. ${ }^{56}$ As in the case of GMOs where many supermarkets have removed GM products from their shelves the supermarkets here were effectively acting as a gauge of and also to preempt the consumer concern associated with beef. On this occasion, where the supermarkets led, the Government felt bound to follow.

Thus, we have seen that the OTMS was designed by the UK, in part, to restore consumer confidence in British beef and hence to stabilise the UK beef market. However, the UK was concerned that the Commission had inappropriately based its even more draconian additional measures (in the shape of an export ban of all cattle and beef products of whatever age) on exaggerated consumer concerns and a desire to stabilise the EU beef market rather than to protect public health. ${ }^{57}$ This does not necessarily indicate double standards on the UK's part. One assumes that the UK was challenging the Commission's measures not because they were based on consumer confidence per se (which would have involved double standards given the basis of the OTMS), but because the Community measures were a disproportionate reaction to the confidence issue. ${ }^{58}$ In any event - whatever its own stance happened to be - the UK was in a position to argue that the Commission's approach was unlawful.

In the event, the UK failed in its argument before the Court. In accordance with its standard case law, the Court ruled that, for a misuse of powers to be established, the Community institution must have adopted the measure with the exclusive or main purpose of achieving an objective other than that specifically provided for. ${ }^{59}$ It stated that, whilst the objectives of the Commission's decision were to be sought in the recitals of the preamble, the recitals had to be considered as a whole rather than in isolation. ${ }^{60}$ Read as a whole, the recitals showed that the Commission was prompted by public health concerns, ${ }^{61}$ and there was no evidence to suggest that the exclusive or main purpose was economic in nature. ${ }^{62}$ The UK National Farmers' Union (NFU) adopted much the same ${ }^{63}$ argument in its indirect, national court

54 There were capacity problems associated with the recommended deboning operations.

55 The BSE Inquiry: The Report (Stationery Office, 2000), paras.7.381-7.382 and 7.387, available at http://www.bseinquiry.gov.uk/report/index.htm. The Report suggests that a third factor may have been a desire to make Europe look more favourably on British beef (para.7.388).

56 ibid., paras.7.382 and 7.387.

57 Neyer (n.45 above) at p.5.

58 I am grateful to Veerle Heyvaert for this observation.

59 Para.64.

60 Paras.65-66.

61 Para.66.

62 Para.67.

63 Though not identical: the NFU's submission was based entirely on consumer concern, as opposed to the UK's argument which, as we have seen, twinned consumer concern with economic purposes of market stabilisation. 
action challenging the export ban ${ }^{64}$ and - naturally enough in a judgment issued on the same day as that in $U K \mathrm{v}$ Commission - the Court effectively echoed the reasoning of its judgment in the direct action. ${ }^{65}$

Finally, Commission v Council ${ }^{66}$ involved a legal base challenge brought by the Commission to a Council Regulation on the traceability of cattle and the labelling of beef. The Commission contended that the Regulation was predominantly a public health measure and thus ought to have been based on Article 100a (now 95), requiring the involvement of the European Parliament (EP) via the co-decision procedure. However, the Council - with which the Court agreed - argued that the measure was more concerned with stabilising the market in beef and restoring consumer confidence via increased transparency. For that reason, the legal base adopted - Article 43 (now 37) relating to agriculture, with its lesser involvement for the EP - was entirely appropriate. The fact that the measure may also have had a public health element did not alter this conclusion, since taking into account public health in the context of measures adopted under Article 43 was entirely appropriate under the third subparagraph of Article 129(1) (now 152(1)) of the Treaty, ${ }^{67}$ and public health was not the principal aim of the measure.

To summarise the position so far, in the $U K \mathrm{v}$ Commission (BSE), $N F U$, and Pfizer cases above, the applicants argued for the annulment of a measure on the explicit ground that it was principally and thus unlawfully aimed at restoring consumer confidence rather than public health. Similar, though more implicit, arguments relating to public concern were also presented in Boehringer, where the applicant claimed that the relevant measure was not necessary for the protection of public health, and in the reasons-related part of the UK's application in UK v Council, where it was argued that the healthbasis of the measure was not scientifically justified. And in Fedesa, the applicant was arguing that neither the public health nor the consumer concern aims of the measure were scientifically justified, and that the measure was not necessary for allaying consumer concern. In all of these cases, in other words, the applicants were contesting the health-basis of the relevant measures. More often than not, the argument (explicit or implicit) was that they were more about tackling public concern than addressing real health issues. In contrast, in Commission v Council ${ }^{68}$ and in the legal base part of the claim in $U K \mathrm{v}$ Council, the applicants argued something like the reverse position - that the relevant measure was principally aimed at protecting public health rather than addressing consumer concern-related issues. However, in neither set of cases were the applicants' arguments

${ }^{64}$ Case C-157/96 R v MAFF, ex parte National Farmers' Union [1998] E.C.R. I2211, para.42.

65 See paras.44-46. Although, reflecting the slightly different submissions of the relevant parties noted at n.63 above, para. 46 speaks of there being no evidence that the main purpose was to allay "consumer concern" (as opposed to the UK case, which speaks of "economic" purposes).

66 Case C-269/97 [2000] E.C.R. I-2257.

67 Which requires the integration of human health protection into all Community policies and activities. This Art., introduced at Maastricht, was not in existence at the time of $U K$ v Council (n.7 above), though as we have seen, the Court there also ruled that health was integral to agricultural policy.

68 n.66 above. 
regarding consumer concern successful. ${ }^{69}$ As we have seen, in the former cases, the Court either held that the relevant measures were predominantly aimed at protecting public health, or that they were appropriately and necessarily aimed at both public health and public concern issues. In the latter cases, it ruled either that health as an objective did not affect the choice of legal base, or that consumer concern and not health was the predominant objective.

What then can we conclude from the examination of the case law presented above? First, it is apparent that in virtually all of the cases in which public concern has been raised, the Court has produced a result upholding the relevant Community measure. ${ }^{70}$ Secondly, it is clear from the cases that, where public concern has been directly raised in EU law, it has been in a negative manner. In other words, the argument is that the EU authorities should not have based the relevant legislative measure on public or consumer concern. There are no positive cases where public interest-type applicants have argued that the authorities ought to have based a measure on public concern but have not done so. In this respect, public concern is unlike the precautionary principle, where there are both cases involving arguments that the Community authorities have been excessively or overly precautionary (negative cases) and cases arguing that they have been insufficiently precautionary (positive cases). ${ }^{71}$

Of course, public concern is also unlike the precautionary principle in that there is no explicit mention of it in the Treaty as a principle which must be taken into account in decision-making. With the precautionary principle, in contrast, there is an explicit statement to this effect in Article $174 \mathrm{EC}$ which has been mainstreamed ${ }^{72}$ as a general principle of law by the Artegodan case. $^{73}$ That said, it is worth recalling that public concern is often closely linked with notions of market stability ${ }^{74}$ and there is of course a duty in the Treaty which requires attention to the creation of such stability. ${ }^{75}$ Nevertheless, it ultimately depends on the specific enabling power or legal base for a relevant measure. If a legal power only allows action to be taken by the Community to protect public health or the environment, then one clearly cannot point to a duty elsewhere in the Treaty to stabilise the market

69 Other than in $U K$ v Council (n.7 above) where, as noted in $n .17$ above, they succeeded on an unrelated, procedural ground.

70 With the exception of $U K \mathrm{v}$ Council, ibid.

71 Albeit that there are relatively fewer of the latter - Heyvaert, "What's in a Name? Assessing the Impact of the Precautionary Principle in European Community Law and Policy", paper presented at IALS, 9 November 2004 (who categorises the cases into "excessive precaution" and "insufficient precaution" challenges).

72 I.e. it has been applied beyond the strict confines of environmental policy in Art.174.

73 Cases T-74/00, T-76/00, T-83/00, T-84/00, T-85/00, T-132/00, T-137/00 and T141/00 Artegodan and Others v Commission [2002] E.C.R. II-4945, para.184.

74 See the very start of this section, where it was suggested that consumer confidence (associated with market stability) may act as a proxy for public concern.

75 Art.33(1)(c) EC within the Agricultural Title, which states that "The objectives of the common agricultural policy shall be ... to stabilise markets". 
as a sole or principal justification for that particular measure. ${ }^{76}$ Equally, if the relevant enabling power allows only action to stabilise the market, then one cannot introduce a measure based solely or principally on public health grounds. Of course, if a power allows for both - as we have seen in some of the case law above - then there is no problem: one can clearly have public health and consumer concern as relevant objectives and either can be given predominant status.

That said, the above assumes a degree of honesty as to legislative purpose. In practice, however, public concern can effectively be disguised. Thus, if a legal power only allows for action on health or environmental grounds and one is being honest, then public concern may only form a minor purpose. However, in practice, there is nothing to stop the Community authorities from disingenuously claiming that a measure is solely or predominantly health/environment-based when it is actually predominantly motivated by public concern. Given the low intensity style of review adopted by the Court in highly discretionary scientific areas, applicants will face an uphill struggle in persuading the Court to intervene in such cases. The only real barrier is the Pfizer case, which requires there to be at least some scientific evidence behind a health/environment measure. ${ }^{77}$ However, while this means that the authorities cannot dress up a public concern measure in the clothing of health/environment if there is no scientific foundation whatsoever, it does not prevent lesser but still significant examples of purpose non-transparency.

Of course, the preceding discussion also presupposes that public health and public concern are separate matters. ${ }^{78}$ If, in contrast, one adopts a less rigid distinction or separation between the two, then it no longer appears disingenuous to claim that, in public concern cases, one is acting on health grounds. Ultimately, it perhaps comes down to the essential fluidity and contestability of the notion of acting on public health grounds. I have taken acting on public health grounds to mean that there are established scientific reasons for doing so. ${ }^{79}$ From this perspective, the distinction drawn between public health and public concern is a real one - public health is scientifically backed and public concern is not. However, it is also perfectly possible to argue that an institution is still, in a sense, acting on public health grounds where there is little or nothing in the way of scientific justification but where the public is nevertheless concerned for its health. From this latter perspective, the distinction drawn between public health and public concern (in a narrow, health risk perception sense) is a tenuous or artificial one. With the MMR vaccine or mobile phone masts for example - if an authority supports the availability of single vaccines or denies planning permission for a mast, can it be said to be acting on public health grounds or solely on the basis of public concern? One's answer will depend not only on one's view of the relevant science but, more importantly, on what one's conception of acting on public health grounds involves.

76 Though if it remains a minor or subsidiary objective, then the Pfizer and UK v Commission (BSE) cases (nn.38 and 46 above, respectively) suggest that there will be no illegality.

77 See the discussion of Pfizer in $\mathrm{n} .135$ below.

$78 C f$., similarly, public concern and science - n. 4 above.

79 ibid. 


\section{Public Concern, the EU and the WTO}

Having examined the place that public concerns surrounding risk activities play in EU case law, it is instructive to see how this compares with the treatment of public concern in WTO jurisprudence. Like the previous section, this one is concerned only with how the issue has been dealt with in the cases themselves (all of which involve the EU). It is beyond the scope of this article to attempt to analyse public concern within EU law or WTO law more generally. ${ }^{80}$

The Beef or Meat Hormones case is central to any such comparison. In the internal context, we have already examined Court of Justice case-law which suggests that the relevant EC Directive banning hormones in beef was driven by consumer anxieties and broader concerns rather than scientificallygrounded safety issues. Not surprisingly, in the external context, similar accusations were levelled at the EU in WTO dispute settlement proceedings. Before the Panel, ${ }^{81}$ Canada stated that the EU measures had been motivated by four sets of concerns: (i) anxiety concerning the danger to human health caused by illegal use of growth promoters; (ii) the pressure of public opinion; (iii) the economic consequences of a "sensationalist campaign", which had produced a collapse in the veal market and a sharp decline in beef sales across the EU; and (iv) distortions in the conditions of competition among EU Member States due to differing regulations on growth hormones. ${ }^{82}$

New Zealand claimed that Article 5 of the SPS Agreement required sanitary or phytosanitary measures which provided a higher level of protection than an international standard, ${ }^{83}$ to be justified by way of a scientific risk assessment. According to New Zealand, no such risk assessment had been carried out in relation to the six hormones which formed the subject of the dispute. While, in its view, "it was evident that consumers in the European Communities might harbour concerns about the use of these substances, consumer perceptions as to risk did not provide a basis for the adoption of measures under Article 5." 84 The US similarly argued that a risk assessment was required because, to be legitimate, a sanitary measure must be seeking to protect the public from a specified risk. According to the US, "the remarkable characteristic of the public debate in the European Communities on these hormones was that the "risk" was usually described in terms of consumer anxieties rather than any observable adverse effect on human health. During the consultations, the European Communities had failed to

80 E.g. analysis of public concern issues associated with EU policy on GMOs, on which see Scott (n.3 above).

81 There are two Panel Reports - one relating to the complaint brought by Canada and the other by the US. Though very similar in content, the two Reports will be considered separately here because there are interesting differences between them in relation to consumer concern. Both are available at http://tradeinfo.cec.eu.int/wtodispute

82 WT/DS48 - Measures affecting livestock and meat (Hormones) - henceforth "Canada", para.IV.6. See also para.IV.10.

83 The relevant international standard here being the one developed by the Codex Alimentarius Commission in relation to growth-hormones.

84 WT/DS26 - Measures affecting meat and meat products (Hormones) - henceforth "US", para.V.28. 
identify any specific risk to human or animal life or health against which the ban was designed to protect." 85

In fairness, however, it does not appear that the EU was claiming that consumer perceptions should have a place within a risk assessment within Article 5, since the US Panel tells us that "none of the parties has argued that factors not listed in Article 5.2, such as consumer preferences, can be taken into account in a risk assessment in accordance with Article 5." 86 The EU was, however, contesting the claim that the purpose of its measures was to allay consumer anxieties rather than to protect human health. At one point in the Panel's report, we are told that the EU "asserted that the historical record clearly demonstrated that the purpose of the measures was to protect human health and animal health from risks arising from the use of the hormones at issue." 87 However, elsewhere in the Panel report, it seems that the EU was in fact denying only that "consumer anxieties" were the sole purpose for which the measures were adopted. ${ }^{88}$ Moreover, the EU was at pains to distinguish between risk assessment, which provides the scientific basis for regulatory action, and risk management, which is the process by which elected representatives decide what action to take in the face of the risk assessment presented to them by the scientists. ${ }^{89}$ According to the EU, such action is likely to be based on a range of factors, including public health, environmental protection, social, economic and political values and consumer concerns. ${ }^{90}$ In the context of the measures on hormones, the EU thus admitted that it was likely that consumer concerns had been taken into account during the risk management phase, since consumer concerns on potential risks to human health resulting from the use of hormones were very high at that time (and were even higher today). ${ }^{91}$ The EU also claimed that it was not alone in doing so - pointing to the way in which consumer concerns had clearly influenced US policy. ${ }^{92}$

Although the Panel could be said to have implicitly accepted this particular argument relating to consumer concern, ${ }^{93}$ it came back to the issue in relation

85 US, para.IV.110.

86 US, para.8.105. The impact of the subsequent Appellate Body (AB) ruling on this particular issue will be considered at the end of this section.

87 Canada, para.IV.14. See also para.IV.18 and US, para.IV.21.

88 US, para.IV.113.

89 US, para.IV.97.

90 ibid. Similar claims have been made by the Commission before the Court of Justice, though the Court itself has never explicitly responded to these (see e.g. Cases T-344/00 and T-345/00 CEVA v Commission [2003] E.C.R. II-229, para.66; and A.G. Alber's Opinion in Case C-248/99 P France v Monsanto and Commission [2002] E.C.R. I-1, para.120).

91 US, para.IV.113 and see also para.IV.14.

92 US, para.IV.113 ("There was little question that consumer concerns about safety and other issues also influenced the US agencies' decisions, even though there was arguably little, if any, basis for those concerns") and IV.124 (citing the US Delaney Clause, relating to additives, which was enacted in the context of public fear of cancer).

93 US, para.8.160. $C f$. the subsequent $\mathrm{AB}$ ruling querying the Panel's distinction between risk assessment and risk management, discussed further at the end of this section. 
to Article 5.5 of the SPS agreement. ${ }^{94}$ Article 5.5 involves three distinct elements, all of which must be demonstrated if a breach of that Article is to be found. First, a Member must have established for itself different levels of sanitary protection in different situations. Secondly, the differences in the levels of protection must be arbitrary or unjustifiable. And finally, those arbitrary or unjustifiable differences must result in discrimination or a disguised restriction of international trade..$^{95}$ For present purposes, we are concerned only with the last of these three elements because it was only in relation to that element that the issue of public concern was raised. The question of whether there had been discrimination or a disguised restriction of international trade was itself raised in relation to three separate factual differences in levels of protection. First, there was the difference in levels of protection between residues of the three natural hormones in dispute when used as growth promoters and residues of the same natural hormones present endogenously ${ }^{96}$ in meat and other foods. ${ }^{97}$ Secondly, there was the difference in levels of protection between the relevant synthetic growth promoting hormones in dispute and natural hormones in dispute present endogenously. ${ }^{98}$ And thirdly, there was the difference between the relevant growth promoting hormones in dispute and carbadox and olaquindox (antimicrobial growth promoters used as feed additives in pig farming). ${ }^{99}$ In answering the question, in all three cases, of whether there had been discrimination or a disguised restriction of international trade within Article 5.5, the Panel drew attention, inter alia, to the objectives other than human health that the EU had had in mind when enacting or maintaining its ban on the use of natural hormones for growth promotion purposes. ${ }^{100}$ By these "other" objectives, the Panel pointed to the EU's objective of harmonising the differing EU Member State schemes, removing barriers to intra-Community trade in beef, increasing the consumption of beef, and reducing beef surpluses. ${ }^{101}$ According to the Panel such action provided more favourable treatment to domestic EU producers. While consumer concern is not explicitly mentioned in the main text here, ${ }^{102}$ it clearly forms the underlying initial impetus to harmonisation: without differing consumer concerns, Member State regulations would not have been so different. Furthermore, when we come, later in the article, to the Appellate Body's (AB) response to this conclusion by the Panel, it will be seen that the $\mathrm{AB}$ examined the issue through much more of a consumer concern lens.

Finally, apparently in order to avoid any misunderstanding as to the scope and implications of the findings in its Report, the Panel was keen to stress, inter alia, that it "had not addressed the ability of any Member to enact

94 Which provides that, in applying their chosen level of sanitary or phytosanitary protection, Members "shall avoid arbitrary or unjustifiable distinctions in the levels it considers to be appropriate in different situations, if such distinctions result in discrimination or a disguised restriction on international trade."

95 Canada, para.8.177.

96 i.e. occurring naturally.

97 Canada, para.8.204.

98 Canada, para.8.210.

99 Canada, para.8.222.

100 Canada, paras.8.207, 8.220, and 8.245.

101 Canada, para.8.207.

102 Though it does appear in Canada, footnote 462. 
measures which are intended to protect not consumer health but other consumer concerns." 103 While the above analysis of consumer concern might be said to give lie to such a claim, it seems that what the Panel had in mind here were regulatory measures such as labelling:

"we are aware that in some countries where the use of growth promoting hormones is permitted in beef production, voluntary labelling schemes operate whereby beef from animals which have not received such treatment may be so labelled."104

Labelling provides a less trade restrictive alternative to import bans. ${ }^{105}$ Instead of public regulators taking into account consumer concerns in deciding to ban imports, imports are allowed, but labelling allows those consumers who perceive there to be a risk or who object on wider grounds, to avoid the relevant product. ${ }^{106}$ This issue has particular resonance in the context of the current EU policy regarding GMOs, ${ }^{107}$ where labelling has been chosen in place of banning imports - although labelling there is mandatory, whereas the Panel above mentions only voluntary schemes. While the labelling element does not form a part of the current dispute relating to the EU's GMO regime, ${ }^{108}$ it seems probable that it will form the basis of a subsequent complaint. It is not likely to be too long therefore before risk labels are tested for their WTO compatibility. ${ }^{109}$

On appeal, public concern came to the fore in relation to the question of discrimination or a disguised restriction on international trade within Article 5.5. In this regard, the $A B$ concerned itself only with the difference in levels of protection between the relevant hormones in dispute and carbadox and olaquindox. ${ }^{110}$ In reversing the Panel's finding that this difference resulted in a disguised restriction on international trade, the $\mathrm{AB}$ appeared to accept that it was legitimate for the EU, with its mandate to establish a common market in beef, to act to address consumer concerns:

103 Canada, para.8.278

104 ibid.

105 On informational approaches to controlling traded product risks, see further Hilson, "Information Disclosure and the Regulation of Traded Product Risks" (2005) 17 J.E.L., forthcoming.

106 Though of course it does not stop others from consuming, which may mean that the relevant wider concerns are not met. For those purely concerned on perceived health risk grounds, labelling is, in contrast, an effective solution.

107 See Scott (n.3 above), pp.24-25.

108 WT/DS291-WT/DS293 - Measures affecting the approval and marketing of biotech products (GMOs). Complaints have been brought by The US, Canada and Argentina regarding the alleged EU moratorium on licensing authorisations.

109 On the WTO compatability of the EU GM labelling regime, see e.g. Morgan and Goh, "Genetically Modified Food Labelling and the WTO Agreements" (2004) 13 R.E.C.I.E.L. 306; Makuch, "TBT or not TBT, That is the Question: The International Trade Law Implications of European Community GM Traceability and Labelling Legislation" (2004) 13 Eur. Env. L. Rev. 226; Hilson and French, "Regulating GM Products in the EU: Risk, Precaution and International Trade" in Cardwell, Grossman and Rodgers (eds.), Agriculture and International TradeLaw, Policy and the WTO (CABI, 2003), p.215.

110 Report of the Appellate Body, WT/DS26/AB/R and WT/DS48/AB/R (henceforth AB Report), para.241. 
"We do not attribute the same importance as the Panel to the supposed multiple objectives of the European Communities in enacting the EC Directives ... The documentation ... makes clear the depth and extent of the anxieties experienced within the European Communities concerning the results of the general scientific studies (showing the carcinogenicity of hormones), the dangers of abuse (highlighted by scandals relating to black-marketing and smuggling of prohibited veterinary drugs in the European Communities) of hormones and other substances used for growth promotion and the intense concern of consumers within the European Communities over the quality and drug-free character of the meat available in its internal market. A major problem addressed in the legislative process of the European Communities related to the differences in the internal regulations of various Member States of the European Union (four or five of which permitted, while the rest prohibited, the use for growth promotion of certain hormones), the resulting distortions in competitive conditions and the existence of barriers to intra-community trade. The necessity for harmonizing the internal regulations of its Member States was a consequence of the European Communities' mandate to establish a common (internal) market in beef."111

What is noteworthy is that while the EU, in its submissions, had claimed that public concerns were relevant to the second element of Article 5.5 (the arbitrary or unjustifiable element), ${ }^{112}$ in relation to the third, disguised restriction element, it had in fact been trying to stress the predominant health motivation for its legislation. ${ }^{13}$ Ironically, the AB was, as we have seen, not at all bothered by the multiple objectives and, in clearing the EU of a breach here, in fact placed most emphasis on the ones based on consumer concern.

Another significant area where public concern has been at issue in WTO disputes is in relation to the concept of "like products" within Article III: 4 of the GATT 1994. ${ }^{114}$ Article III: 4 states that:

"The products of the territory of any Member imported into the territory of any other Member shall be accorded treatment no less favourable than that accorded to like products of national origin in respect of all laws, regulations and requirements affecting their internal sale, offering for sale, purchase, transportation, distribution or use."115

In the Asbestos case, the Panel initially found that chrysotile asbestos fibres were "like" PVA, cellulose and glass fibres and, subsequently, that cementbased products containing chrysotile asbestos fibres were "like" cement-

111 AB Report, para.245.

112 AB Report, para.33.

113 AB Report, para.244.

114 Scott (n.3 above), p.24.

115 Emphasis added. 
based products containing PVA, cellulose and glass fibres. ${ }^{116}$ On appeal, the $\mathrm{AB}$ reversed these findings. Like the Panel, it employed what has become a standard approach for analysing likeness, using four general criteria: the properties, nature and quality of the products; the end-uses of the products; consumer tastes and habits, or consumer perceptions and behaviour in respect of the products; and the tariff classification of the products. ${ }^{17}$ For present purposes, it is of course the third criterion, consumer tastes and habits, that is of most interest. The Panel had declined to take a position on this third criterion, on the basis that it would not provide clear results because tastes and habits are "very varied". ${ }^{118}$ However, the AB stated that a panel could not decline to look into relevant evidence just because it may not be clear. ${ }^{119}$ In any event, the $\mathrm{AB}$ seemed to think that consumer tastes and habits were quite clear here. According to the $\mathrm{AB}$, there was a proven health risk (of cancer) associated with chrysotile asbestos fibres. ${ }^{120}$ Consumer perceptions of the risk associated with the different fibres and their associated products were therefore, inevitably, different; and these perceptions and the purchasing behaviour associated with them lent weight to the view that the fibres and their associated products were not "like". ${ }^{121}$

The issue of like products within Article III: 4 was also raised in the Meat Hormones case. Here, the EU claimed that meat from animals treated with hormones was perceived by consumers as a distinct product and offered this as one of the reasons why growth hormone meat and ordinary meat could not be considered as like products. ${ }^{122}$ Canada argued that the perception of European consumers should not be relevant in determining the likeness of a product. In Canada's opinion:

"The public authorities of WTO Members had a responsibility to educate the public and to make them aware of scientific facts. If the Panel were to allow "public perception" to become a factor in a "like product" determination, it would open the door to misapprehensions concerning scientific facts becoming the basis of a justification in the WTO for the adoption of discriminatory measures. Such an interpretation would obviously remove any incentive whatsoever for public authorities in the European Communities to make their populations aware of the scientific facts in respect of the six hormones at issue." 123

In the event, the Panel and $\mathrm{AB}$ decided that the dispute fell to be decided by the SPS Agreement and not the GATT and thus the submissions on Article III: 4 were not addressed. This left open the crucial question of whether

116 WT/DS135 - Measures affecting the prohibition of asbestos and asbestos products, paras.8.144 and 8.150 .

117 WT/DS135/AB/R, para.101.

118 Panel Report, para.8.139.

119 Para. 120

120 Para. 122.

121 ibid.

122 Canada, para.IV.338; US, para.IV.254.

123 Canada, para.IV.348. Canada has put forward a similar claim in the current GMOs dispute - see n.108 above, Canada, First Written Submission, paras.317318, available at http://www.genewatch.org/WTO/WTO_Submissions.htm 
consumer perceptions of risk are relevant to the determination of product likeness only when - as in the Asbestos case - the health risks are scientifically proven. Alternatively - as in Meat Hormones - can consumer perceptions of risk also be taken into account where no scientific proof of harm has been firmly established? The GMOs dispute should cast some much needed light on this, as well as on the question of whether consumer perceptions as to process characteristics count in the same way as those associated with the physical character of the product itself. ${ }^{124}$

Finally, it is worth noting the possible implications which the AB's ruling on the scope of risk assessment has for the role of public concern. The Panel, reflecting the submissions of the parties, ${ }^{125}$ drew a distinction between risk assessment and risk management, stating that the former was scientific and the latter a non-scientific, policy exercise involving social value judgments made by political bodies. ${ }^{126}$ The $\mathrm{AB}$ took issue with this apparently rigid distinction - which the Panel had employed to support a restrictive notion of risk assessment - holding that it had no basis in the text of the SPS Agreement. ${ }^{127}$ What the $\mathrm{AB}$ was keen to allow as part of risk assessment was the human failings in terms of, for example, regulatory enforcement, which may have a key bearing on risks as they are found in the real world, as opposed to the laboratory. ${ }^{128}$ However, it is rather a large jump from saying that risk assessment need not be confined to the laboratory-based, physical sciences to a claim that it should also encompass public concerns or anxieties in a more general sense. Public concerns may be relevant in a risk assessment if they are able to reveal, for example, particular frames or risk pathways which the experts may have missed. ${ }^{129}$ Nevertheless, more general public anxiety about remaining uncertainties is probably not a legitimate factor for risk assessment under the SPS Agreement. ${ }^{130}$

\section{Conclusion}

A comparison of the EU and WTO case law analysed above reveals some interesting points on which to conclude. What we find is that the EU, as an internal actor, is rather more constrained than it is as an external actor in its formal ability to take account of public concerns. Internally, the EU is constrained by the terms of its legislation in the various risk fields. ${ }^{131}$ If the relevant power allows only for action on health or environmental grounds, then the EU cannot rely on public concern - at least not formally and

124 ibid.

125 See e.g. n. 89 above.

126 See n.93 above.

127 Which does not use the phrase risk management. AB Report, paras.181 and 2056.

128 AB Report, para. 187.

129 Winickoff et al., n.2 above; cf. also n.4 above.

130 As the AB states in its Report in Meat Hormones (at para.186): “. . . the Panel opposes a requirement of an 'identifiable risk' to the uncertainty that theoretically always remains since science can never provide absolute certainty that a given substance will not ever have adverse health effects. We agree with the Panel that this theoretical uncertainty is not the kind of risk which, under Article 5.1, is to be assessed." See also US Panel, para.8.153, and n.4 above. It is also hard to see other e.g. ethical/political public concerns being held to be relevant.

131 To similar effect, see Scott (n.3 above) p.22. 
explicitly - as a sole or predominant objective. This is true at both the risk assessment and risk management phases. ${ }^{132}$

The AB ruling in the Meat Hormones case makes it clear, however, that the EU is much more free in terms of at least one of the WTO disciplines. Under the SPS Agreement, there must be an initial risk assessment on which the relevant measure is based, and public concern ${ }^{133}$ cannot be considered as part of that scientific assessment. However, thereafter, the EU is formally and explicitly able to take into account public concern at the risk management stage. ${ }^{134}$

In many ways, this is an ironic outcome, with WTO law seemingly giving more ground for the formal and explicit consideration of public concern than EU law. After all, it is not often that the WTO is considered to be more supportive of democracy than the EU. Of course, one might respond that to consider only the formal position is misplaced: after all, the EU can, as we have seen, surreptitiously act explicitly on scientific, public health or environmental grounds but as a cloak for public concern. And in doing so, it may be supported by a substantive version of the precautionary principle. ${ }^{135}$ However, I would argue that public concern should be recognised as a legitimate ground for action in its own right rather than being hidden in this manner. ${ }^{136}$ It makes no sense for the EU to argue one thing externally before the WTO and not be in a position to own up to it internally. There are two options. The first would be for the EU to examine its various, individual legal powers in the Treaty and elsewhere to see where public concern could be introduced as a relevant formal and explicit objective or consideration. As things stand, the existing market stability consideration within the Agriculture Title plays a somewhat limited role and, in any event, provides a rather indirect expression for public concern. More promising is, for

132 We are back, here, to the scope of public concern discussed in n.4 above. Scientifically justified public concerns can almost certainly be considered at both phases.

133 Again, unless scientifically justified.

134 Although, as we have seen, the AB cast doubt on the Panel's distinction between risk assessment and risk management, this was because of its restrictive effect on the scope of risk assessment. In principle, it remains useful to conceive of the post risk assessment elements of the SPS agreement (in particular Arts.5.4-5.6) as issues of risk management. The issue may be revisited in the forthcoming GMOs case (n.108 above - see the EU's Second Written Submission, paras.21-28, available at http://trade-info.cec.eu.int/wtodispute).

135 i.e. the principle that one should be prepared to take action to protect human health or the environment even where there is scientific uncertainty about likely harm. Nevertheless, the Pfizer case makes it clear that the precautionary principle does not allow for measures based on hypothetical risks - there must be at least some scientific evidence of a risk (n.38 above, paras.140-146); cf. A.G. Mischo's Opinion in Fedesa, n.14 above, at para.17, allowing "purely hypothetical" risks to be tackled, which must now be considered wrong.

136 To similar effect see Lee, EU Environmental Law (Hart Publishing, 2005) ch.9 (and also Lee, "Agricultural Biotechnology in the UK: Expanding the Debate?" in Everson, Scott \& Vos (eds), Uncertain Risks Regulated, forthcoming ), who argues that although public concern may have motivated a regulatory decision, it is often hidden away, with science made out to be the real justification. Lee, quite rightly, argues that this is harmful in terms of transparency and accountability. 
example, the GM Food and Feed Regulation, which permits the Commission, in issuing its draft authorisation risk management decision, to take into account "other legitimate factors" beyond just the scientific risk assessment. ${ }^{137}$

Alternatively, there could be a greater re-orientation of the precautionary principle along procedural, participatory lines, ${ }^{138}$ so that the existing legal duty to take into account the precautionary principle itself takes care of the issue of public concern. ${ }^{139}$ The advantage of this second option is that no Treaty or legislative amendments would be needed: the EU would be acting on existing health or environmental grounds/bases within the Treaty, but public concern would be seen as part and parcel of these via the precautionary principle. My own preference is for the former option: the danger with the latter is that it would further muddy the already murky waters of the precautionary principle, and taint what scientific respectability and mileage there is in the substantive version with what many will however wrong-headedly - regard as the uninformed prejudices of populism. Whichever solution is adopted, considerable thought will have to be given as to how public concern is gauged and what pre-conditions are necessary for it legitimately to be taken into account. As Scott rightly notes, the last thing we want in the EU is the "uncritical, aggregation of ill-informed public preferences" 140 and some form of civic republican-type testing of public opinion will be needed in order to avoid this. ${ }^{141}$

137 See Recital 32 and Art.7(1) of Reg. 1829/2003 on Genetically Modified Food and Feed [2003] O.J. L268/1. See further Lee, n.136 above.

138 See $e . g$. Fisher, "Is the Precautionary Principle Justiciable?" (2001) 13 J.E.L. 315 at p.320.

139 To similar effect, see Scott and Vos (n.21 above) p.279. Existing EU policy documents on the precautionary principle already make the link with public concern and stress the need for public involvement in risk regulation (see Council Resolution On The Precautionary Principle, Annex II to the Nice Presidency Conclusions 7, 8 and 9 December 2000, available at http://ue.eu.int/ueDocs/cms Data/docs/pressData/en/ec/00400-r1.\%20ann.en0.htm; and the Commission Communication on the Precautionary Principle, $\operatorname{COM}(2000) 1$, paras. 1 and 6.2 and para. 5 of the summary).

140 Scott (n.3 above) at p.26.

141 Scott makes some proposals of this type-ibid., pp.28-29. See also Scott and Vos (n.21 above) pp.284-286. 